\title{
Schweighardt Zsanett[1]: Az áldozatsegítés megvalósulási formái az Európai Unió egyes tagállamaiban
}

Debreceni Jogi Mühely, 2009. évi (VI. évfolyam) 2. szám (2009. április)

\author{
„Ha a társadalom nem tudja megvédeni egyes állampolgárait attól, \\ hogy büncselekmény áldozataivá váljanak, akkor legalább, \\ ha bajba kerültek, próbáljunk meg rajtuk segíteni." \\ (Az európai áldozatvédő szervezetek alapgondolata)
}

\section{Bevezetés, avagy a helyreállító koncepció térnyerése napjainkban}

Napjainkra a hétköznapi kockázatok része lett a bünözés. A közbiztonság iránti igény politikai szempontként jelenik meg, mivel a büncselekmények következményeinek feldolgozása az állami büntetőpolitika feladata. A büntető igazságszolgáltatás területén a XX. század '80-as éveitől előtérbe került a helyreállító (resztoratív) koncepció, amely a büncselekményt elsődlegesen az áldozatnak okozott sérelemként, azaz konfliktusként definiálja, és csak másodsorban a jogi norma megsértéseként, azaz jogi tényként. A bünt személy-személy közötti konfliktusként, nem pedig állam-személy közötti konfliktusként kezeli. A büntető igazságszolgáltatásban az áldozat szerepe ezzel megerősödik. A büntetés célja már nem csupán a megsértett jogrend helyreállítása és a megtorlás (jogépségi büntetés) alkalmazása, hanem a sértettnek való elégtételadás és az okozott kár megtérítése, a restitúció is célként szerepel. Az eljárás az elkövető viselkedéseinek következményeire reagál, jövőre tekintő funkciója van. Míg a megtorló rendszerben az elkövető felelőssége a tett miatt az állammal szemben állt fenn, addig a helyreállítás során az elkövető a sértettnek és a közösségnek is felelős, vállalja a felelősséget a tettért. A dialógus az áldozat, az elkövető, az állam és a közösség tagjai között jön létre. Mindeközben az állam az eljárás során csupán őrködik a felett, hogy tisztességes eljárás útján realizálódjon az elkövető felelőssége az állammal és a közösséggel szemben. A resztoratív rendszerben a megsértett egyén magánjogi érdeke kerül előtérbe, kiemelten fontossá válik az anyagi károk, és a pszichés-érzelmi sérülések kompenzálása. A modern demokratikus államok ezért különös hangsúlyt helyeznek a büncselekmények áldozatai jogainak érvényesítésére, és szabályozzák a társadalmi, a morális és az anyagi sérelem enyhítésének feltételrendszerét és módozatait. A közbéke érdekében elősegítik az elkövető és az áldozat közötti hatékony kommunikációt.

\section{Az áldozatsegítés föbb nemzetközi dokumentumai}

Az ENSZ 1985. évi, „A büncselekmények és a hatalommal való visszaélés áldozatainak nyújtandó igazságszolgáltatás alapelveiről” szóló deklarációja alapján az áldozatnak orvosi, pszichológiai és szociális segítséghez van joga állami, önkéntes, közösségre alapozott és egyéni megoldások alkalmazásával. Emellett a jogi segítségnyújtást és az információt is biztosítják számukra.

Az Európa Tanács 1987. évi 21. számú ajánlásában az áldozatoknak történő segítségnyújtás következő típusait említi:

- elsősegély jellegü sürgős segítség,

- folyamatos egészségügyi, pszichológiai, szociális és anyagi támogatás,

- az ismételt áldozattá válás elkerülése érdekében történő tanácsadás,

- segítségnyújtás az eljárásban a kárenyhítés igénybevételéhez,

- jogi tanácsok a vagyoni kár megtérítése érdekében. 
Az Európai Áldozatvédő Fórum (European Forum for Victim Services) 1998-as, „A büncselekmények áldozatainak szociális jogai" címü nyilatkozata kiemeli az áldozatok ingyenes áldozatsegítő szolgáltatásokhoz való jogát.

Az Európai Tanács már az 1999. október 15-16-i tamperei ülésén hangsúlyozta a büncselekmények áldozatainak védelmével kapcsolatos minimumszabályok kidolgozásának szükségességét, különösen a büncselekmények áldozatainak igazságszolgáltatáshoz való hozzáférésével, valamint kártérítéshez füződő jogaikkal kapcsolatban.

Az Európai Unió Tanácsa 2001. március 15-én kerethatározatot fogadott el „Az áldozatok jogállásáról a büntetőeljárásban" címmel (2001/220/JHA), amely lehetővé teszi a büncselekmények sértettjei számára, hogy azok a büntetőeljárás során kártérítést követeljenek az elkövetőtől.

Az Európai Unió szintjén az áldozatok kártalanítását a Tanács 2004/80/EC irányelve (2004. április 29.) szabályozza, amely „A büncselekmények áldozatainak kompenzációjáról” címet viseli. Ennek értelmében a szándékos és erőszakos büntetőjog-ellenes (elegendő a formai tényállásszerüség, azaz a materiális jogellenesség) cselekmények áldozatai számára állami kárenyhítést kell biztosítani. Kárenyhítésre csak az a természetes személy áldozat jogosult, akinek sérelmére szándékos, személy elleni erőszakos büntetőjog-ellenes cselekményt követtek el, s ennek következményeként testi épsége, egészsége súlyosan károsodott. Ezek a személyek a büncselekmény közvetlen fizikai sértettjei. Kárenyhítésre jogosult továbbá az a természetes személy is, aki a szándékos, személy elleni erőszakos büntetőjog-ellenes cselekmény következtében testi épségégében, egészségében súlyosan károsodott sértettnek vagy meghalt személynek az elkövetés időpontjában egy háztartásban élő egyenes ági rokona, örökbefogadója és nevelőszülője, örökbe fogadott és nevelt gyermeke, házastársa, élettársa, továbbá akinek eltartására a sértett jogszabály, végrehajtható bírósági, illetőleg hatósági határozat vagy érvényes szerződés alapján köteles volt.

Valamennyi tagállam köteles gondoskodni arról, hogy a területükön szándékosan elkövetett erőszakos büncselekmények áldozatainak nyújtott kárenyhítés tekintetében nemzeti jogszabályok biztosítsák az áldozatok számára az igazságos és megfelelő kárenyhítést. Kárenyhítésnek az államterületen belüli és a határokon átnyúló tényállások esetében egyaránt rendelkezésre kell állnia. Az irányelv arra nézve tartalmaz rendelkezéseket, amikor a szándékos, erőszakos büncselekmények elkövetése más tagállamban történt, mint amelyben a kárenyhítést igénylő (áldozat) szokásosan tartózkodik, és a kárenyhítés iránti kérelem előterjesztését a kérelmező tartózkodási helye szerint is lehetővé teszi. A kárenyhítést azonban minden esetben az a tagállam köteles megfizetni, amelynek a területén a büncselekményt elkövették

A kerethatározat értelmében a büncselekmények áldozatait az alábbi jogok illetik meg:

- a tisztelethez és elismeréshez való jog,

- a meghallgatáshoz és a bizonyítékok szolgáltatásához való jog,

- az információhoz való jog,

- a kommunikációs garanciákhoz való jog,

- a speciális támogatáshoz való jog,

- a büntetőeljárással kapcsolatos kiadások megtérítéséhez való jog,

- a fokozott védelemhez való jog,

- a kárenyhítéshez való jog,

- a mediációhoz való jog 
Az állam által az áldozatok számára nyújtott kárenyhítés nem fájdalomdíj, és nem jár automatikusan. Ennek megfelelően az államnak az ésszerüség határain belül mindent meg kell tennie annak érdekében, hogy az elölegként kifizetett összeget az arra egyébként kötelezett (például: az elkövető, a biztosító, a munkáltató, vagy szerződés, hatósági, bírósági döntés alapján az erre kötelezett) az államnak megfizesse.

A kerethatározat kimondja, hogy minden tagállam köteles előmozdítani az áldozatokat segítő szakszolgálatok bekapcsolódását az áldozatsegítési eljárásokba. A tagállamok ezt vagy áldozatsegítő szakemberek útján, vagy áldozatsegítő szervezetek elismerésével és támogatásával valósíthatják meg. A kerethatározat felülvizsgálatára 2009. január 1-jéig kell, hogy sor kerüljön, az európai Bizottság eddig köteles jelentést terjeszteni az irányelv alkalmazásáról az Európai Parlament, a Tanács valamint az Európai Gazdasági és Szociális Bizottság elé.

\section{Egyes EU tagállamok áldozatsegítési gyakorlata}

A bünelkövető általi jóvátétel, illetve az állam általi kárenyhítés országonként eltérő megnyilvánulási formáit az alábbi kérdések mentén vizsgáljuk:

\section{A.) AZ ELKÖVETŐ ÁLTAL NYÚJTOTT KÁRTÉRÍTÉS 1. A kártérítési igény érvényesítésének feltételei Ausztria}

A büntetőeljárásban a büncselekmény miatt sérelmet szenvedett személyeknek lehetőségük van kártérítés érvényesítésére annak kijelentésével, hogy a büntetőeljárásban félként kívánnak részt venni. A kártérítés az áldozat által az államilag üldözött büncselekmény eredményeként elszenvedett anyagi veszteségek vonatkozásában kérhető. Nem alapozza meg tehát a kártérítési igény érvényesítését, ha a sértett pénzben kifejezhető veszteséget nem eredményező eszmei érdekei sérültek.

\section{Németország}

A büntetőeljárásban a büncselekmény sértettje vagy örököse érvényesítheti a vádlott ellen a helyi bíróságok hatáskörébe tartozó és bírósági úton még nem érvényesített, büncselekményböl származó vagyonjogi igényét.

\section{Egyesült Királyság}

- Anglia és Wales

Sértettek nem igényelhetnek kártérítést a büntetőeljárás folyamán, és erre nincs is szükség. Minden olyan esetre, amikor a büncselekmény személyi sérülést, kárt vagy veszteséget okozott, a Büntetőbíróságok (ítélethozatali) hatásköréről szóló 2000. évi törvény előírja az angliai és walesi büntetőbíróságok számára, hogy mérlegeljék, kötelezhető-e az elkövető kártérítés nyújtására a sértett(ek) javára. Amennyiben a bíróság a fenti esetekben nem ad ki kártérítési végzést, köteles ezt a döntését megindokolni.

- Skócia

Magánszemélyek nem igényelhetnek kártérítést a büntetőeljárás folyamán. A kártérítési végzés kiadása a bíróság hatáskörébe tartozik. Az 1995. évi (skóciai) büntetőeljárási törvény értelmében, amennyiben valamely személyt egy büncselekményért elítélnek, a bíróság elrendelheti, hogy az elkövető a büncselekménynek minősülő cselekmények által közvetve vagy közvetlenül okozott személyi sérülésért, kárért vagy veszteségért kártérítést fizessen. A bíróság az elkövetőt erre az egyébként kirótt büntetés helyett vagy annak kiegészítéseként is 
kötelezheti végzésében. Döntése meghozatalakor a bíróság számos körülményt tekintetbe vesz, ideértve az ügyben hozott jogerős ítéletet és az érintett fizetöképességét is.

- Észak-Írország

Sértettek nem igényelhetnek kártérítést a büntetőeljárás folyamán, és erre nincs is szükség. Arra az esetre, amikor az elkövetőt valamely büncselekményért elítélik, az 1994. évi (északírországi) büntető igazságszolgáltatásról szóló rendelet elöírja az észak-írországi büntetőbíróságok számára, hogy mérlegeljék, kötelezhető-e az elkövető kártérítés nyújtására. Kártérítési végzés adható ki a szóban forgó vagy bármely olyan büncselekményből származó személyi sérülés, kár és veszteség kapcsán, amelyet a bíróság az ítélet kiszabása során tekintetbe vesz. Amennyiben a bíróság a fenti esetekben nem ad ki kártérítési végzést, köteles ezt a döntését megindokolni.

\section{Franciaország}

A büntetőeljárási kódex 2. cikke értelmében a büncselekmény, vétség vagy szabálysértés miatt elszenvedett kár megtérítése iránti kártérítési kereset indításának joga mindazokat megilleti, akik a büncselekmény által közvetlenül okozott kárt személyesen elszenvedték.

A kártérítés igényléséhez tehát elegendő igazolni a büncselekmény által okozott kár létezését, az igényelt összegek maximálása nélkül (a büntetőeljárási kódex 420-1. cikke).

\section{Magyarország}

A büntetőeljárásról szóló 1998. évi XIX. törvény (Be.) szerint a sértett (mint magánfél) a terhelttel szemben azt a polgári jogi igényt érvényesítheti, amely a vád tárgyává tett cselekmény folytán keletkezett, azaz a büntetőeljárásban a terhelt csak a büncselekménnyel okozati összefüggésben keletkezett kár megfizetésére kötelezhetö.

\section{A kártérítési igény érvényesítésének lehetőségei az eljárás egyes szakaszaiban} Ausztria

A Büntetőeljárási törvénykönyv 47. szakaszának (1) bekezdése elöírja, hogy a sértett a büncselekményből eredő magánjogi jogait a bírósági eljárás megindulásáig terjessze elő. Az ítélkezési gyakorlat azonban lehetővé teszi a sértettnek, hogy bekapcsolódjon az eljárásba.

\section{Németország}

A kérelem már a nyomozati eljárásban előterjeszthető, még a büntetőeljárás bírósági szakba jutása előtt, illetve még a fötárgyaláson is, a perbeszédek kezdetéig.

\section{Egyesült Királyság}

- Anglia és Wales

Nem alkalmazható - ezzel az eljárás megfelelő szakaszában a bíróság foglalkozik.

- Skócia

Nem alkalmazható - ezzel az eljárás megfelelő szakaszában a bíróság foglalkozik.

- Észak-Írország

Nem alkalmazható - ezzel az eljárás megfelelő szakaszában a bíróság foglalkozik.

\section{Franciaország}

A kártérítési igény már a nyomozási és eljárási szakaszban bejelenthető. A büntetőeljárási kódex 53-1. és 75. cikke előírja, hogy a bünügyi rendőrhatóságok minden eszközzel kötelesek tájékoztatni a sértetteket jogaikról és különösen arról, hogy az elszenvedett károkért jogukban 
áll kártérítést kérni. Az igény azonban még a vizsgálat időpontjában, illetve akár az ítélethirdető tárgyaláson is bejelenthető.

\section{Magyarország}

A polgári jogi igényt a büntetőeljárás megindításától legfeljebb az elsőfokú bíróság határozathozatal céljából tartandó tanácsüléséig lehet bejelenteni.

\section{A kártérítési igény bejelentésének módja}

\section{Ausztria}

A sértettnek a büncselekményből eredő magánjogi jogok érvényesítése érdekében történő beavatkozása (magánfélként történő beavatkozás) nem képez keresetet, azaz formailag nem összehasonlítható a polgári jog alapján indított keresettel. Elegendő - egy alakiságokhoz nem kötött - nyilatkozat az elszenvedett károsodásért történő kártérítés igényléséről és evégett a büntetőeljárásban félként való részvételröl. A Büntetőeljárási törvénykönyv nem állapít meg külön eljárást a magánfélként történő részvételre.

Ehelyett az ügy bejelentésekor szóban jegyzőkönyvbe mondhatja, a tanúknak a rendfenntartó szervek (rendőrség, csendőrség) vagy az előkészítő bírósági tárgyaláson a vizsgálóbíró általi meghallgatásakor, vagy a bírósági eljárás során is. A félként való fellépés írásbeli bejelentéséhez szintén nem szükséges ügyvédi képviseletet igénybe venni. Az említett bejelentés megadja a sértettnek a magánféli jogállást (a Büntetőeljárási törvénykönyv 47. § (1) bek.), és ezt követően a büntetőeljárásban félként vesz részt

\section{Németország}

Az igény érvényesítésére szolgáló kérelmet írásban - az ügyészség, vagy vádemelést követően a bíróság előtt - kell benyújtani, vagy azt szóban jegyzőkönyvbe mondhatja a bíróság hivatalvezetője előtt, továbbá azt még a főtárgyaláson szóban is elö lehet terjeszteni. Illetékes az az ügyészség, amely a vádlott ellen a nyomozást vezeti, valamint az a bíróság, amely előtt a vádemelés történt.

\section{Egyesült Királyság}

- Anglia és Wales

Nem alkalmazható - ez a bíróság hatáskörébe tartozik.

- Skócia

Nem alkalmazható - ez a bíróság hatáskörébe tartozik.

- Észak-Írország

Nem alkalmazható - ez a bíróság hatáskörébe tartozik.

\section{Franciaország}

$\mathrm{Az}$ államügyész beleegyezésével a sértett a rendőrségi nyomozás folyamán a bünügyi rendőrség felügyelőjének vagy tisztviselőjének jelentheti be kártérítési igényét, aki arról jegyzőkönyvet vesz fel. Ezenkívül a bejelentés megtehető a bírósághoz legalább 24 órával a tárgyalás időpontja előtt beérkező faxban vagy tértivevényes ajánlott levélben. A sértett azonban még a tárgyaláson személyesen megjelenve is támaszthat magánjogi követelést.

\section{Magyarország}

A polgári jogi igényt a sértett (akinek jogát vagy jogos érdekét a büncselekmény sértette vagy veszélyeztette), halála esetén az örökös, a Polgári perrendtartásban meghatározott feltételek 
esetén pedig az ügyész érvényesítheti. A sértett a vádirat benyújtása előtt a nyomozó hatóságnál, ügyészségnél, azt követően a bíróságnál nyújthatja be a polgári jogi igényt.

\section{A kártérítési igény előterjesztésének formai kellékei Ausztria}

Az eljárásban magánfélként történő részvételre vonatkozó nyilatkozatban nem kell megadni a kért kártérítés tényleges összegét, azonban természetesen hasznos a követelt összeg megjelölése. Ha az igények különféle ténybeli körülményeken és jogalapokon nyugszanak (például kórházi költségek és a fájdalomdíj), legkésőbb a bírósági eljárásban meg kell határozni a kért összeget.

\section{Németország}

A kérelemnek határozottan meg kell jelölnie az igény tárgyát és indokait. Szabály szerint a követelt pénzösszeget kell megjelölni, ettől el azonban lehet tekinteni, ha az összeg nagyságát előbb szakértőnek kell megállapítania, vagy ha a fájdalomdíjigény a bíróság mérlegelésétől függ.

\section{Egyesült Királyság}

- Anglia és Wales

Nem alkalmazható - ez a bíróság hatáskörébe tartozik.

\section{- Skócia}

Nem alkalmazható - ez a bíróság hatáskörébe tartozik. A megrongálódott dolgok értékével kapcsolatos információk rendszerint az ügyész birtokában vannak, aki megfelelö időben a bíróság elé terjeszti azokat.

- Észak-Írország

Nem alkalmazható - ez a bíróság hatáskörébe tartozik.

\section{Franciaország}

Az igény számszerüsíthető kártételek szerint, amennyiben testi, anyagi károkra vonatkozik, illetve összesített módon, amennyiben erkölcsi kárról van szó. Az igényhez azonban minden igazoló okmányt csatolni kell.

\section{Magyarország}

A követelés bejelentési formájára és összegszerüségére nincs törvényi elöírás. Az igényérvényesítés konjunktív feltétele, hogy a sértett az igényét bejelentse, illetve az, hogy ezt az elévülési időn belül tegye meg. A büntetőeljárásban érvényesíteni kívánt polgári jogi igény jogalapja és összegszerüsége tekintetében polgári jogi és munkajogi szabályok irányadók. A magánfél a tényleges kárán kívül elmaradt hasznát, kamatot, készkiadásait, valamint képviselője díjának megfizetését kérheti. A törvény lehetőséget biztosít arra is, hogy a sértett ne csak kötelmi jogi kártérítési igénnyel lépjen fel, hanem a dolog kiadását kérje, birtokvédelmi igénnyel is felléphet, kérheti a terhelttől az elfogyasztott, illetve a beszedni elmulasztott hasznok értékét. Becsületsértés, rágalmazás, hamis vád esetén kérheti a sértett elégtételadásra kötelezni a terheltet. A nemvagyoni kár (élet, testi épség, egészség, emberi méltóság sérelme esetén) is érvényesíthető az adhéziós eljárás keretében, azonban ez a gyakorlatban ritka.

\section{A sértett jogi segítségnyújtásra jogosultsága az eljárás egyes szakaszaiban Ausztria}


Függetlenül attól, hogy a büntetőeljárás megindult-e, a sértetteknek az „első ügyvédi vélemény" keretében ingyenes jogi tanácsadás áll rendelkezésükre minden kerületi bíróságon. Továbbá a büntetőeljárásokban közremüködő valamennyi hatóságnak el kell magyaráznia a sértettek számára jogaikat (a Büntető törvénykönyv $47 . \quad \S(1)$ bek.), folyamatosan tájékoztatniuk kell őket a folyó büntetőeljárásról, amennyiben kétség merül fel abban, hogy arról tudomással bírnak (a Büntető törvénykönyv 365. § (1) bek.), és hivatali eljárásuk részeként figyelembe kell venniük az általuk a büncselekmény eredményeként elszenvedett sérelmeket és a magánjogi következményekkel járó bármely más lényeges körülményt (a Büntető törvénykönyv 365. § (1) bek.).A büntetőeljárásban magánfélként eljáró sértettet képviselheti ügyvéd, bár az ügyvédi képviselet nem kötelező.

A kiskorú veszélyeztetése és fajtalanság kiskorú áldozatai az eljárás során - a feljelentéstöl a büntetőeljárás lezáródásáig - jogosultak ingyenes ügyvédi képviseletre, egyfajta „eljárási támogatásként" Nincsen azonban általános költségmentességi rendelkezés a magánfélként eljáró felek ügyvédi képviseletére.

\section{Németország}

Az igényt érvényesítő a vádemelést követően kérhet költségmentességet a kérelem vonatkozásában, ha személyi és vagyoni körülményei miatt az eljárás költségeit nem vagy csak részben, illetve részletekben képes megfizetni. Ezen kívül a szándékolt jogérvényesítésnek a per pozitív kimenetelét illetően elegendő eséllyel kell rendelkeznie, és nem lehet rosszhiszemü.

\section{Egyesült Királyság}

- Anglia és Wales

Igen, azonban a sértettnek magának kell eldöntenie, szüksége van-e arra, hogy ügyvéd képviselje.

\section{- Skócia}

Igen, azonban a sértettnek magának kell eldöntenie, szüksége van-e arra, hogy ügyvéd képviselje.

- Észak-Írország

Nem.

\section{Franciaország}

A jogsegély biztosításáról a 2002. szeptember 9-i törvény rendelkezik, amit a legsúlyosabb büncselekmények sértettjei anyagi megkötés nélkül igénybe vehetnek. Más sértettek esetében az igénylés anyagi feltételhez kötött. Ez a segítség az eljárás kezdetétől igénybe vehető, mivel a bünügyi rendőrség már a nyomozási és eljárási szakasz elején köteles tájékoztatni a sértettet arról, hogy jogában áll ügyvédi segítségét kérni, akit esetlegesen az ügyvédi kamara elnöke jelöl ki.

\section{Magyarország}

A polgári jogi igény elbírálása során a magánfelet ki kell oktatni annak következményeiröl.

Az Igazságügyi Minisztérium által felügyelt Igazságügyi Hivatal a büntetőeljárás előtt áldozatsegítő szolgáltatásként a sértetteknek kérelmükre illeték- és díjmentesen jogi felvilágosítást és tanácsadást ad (szakjogászi segítségnyújtás). A büncselekmények áldozatainak segítéséről és az állami kárenyhítésről szóló 2005. évi CXXXV. törvény alapján ugyanis a területi áldozatsegítő szolgálat az eset összes körülményeinek mérlegelése után a 
büncselekmény következtében jogaiban sérelmet szenvedett áldozatnak jogi tanácsot és segítséget ad a sérelem rendezéséhez. Ha a körülmények alapján bebizonyosodik, hogy a rászoruló áldozat sérelmének rendezéséhez a jogi segítségnyújtásról szóló 2003. évi LXXX. törvényben meghatározott szakjogászi támogatásokra van szükség, a területi áldozatsegítő szolgálat továbbítja a kérelmet az Igazságügyi Hivatal Jogi Segítségnyújtó Szolgálata területi szolgálatának, amely a döntéséről és a megtett intézkedésekröl haladéktalanul értesíti a területi áldozatsegítő szolgálatot.

\section{A kártérítési igény alapjának és mértékének bizonyítása}

\section{Ausztria}

A bíróságnak hivatali eljárása során figyelembe kell vennie a büncselekmény eredményeként elszenvedett sérelmeket és a magánjogi következményekkel járó bármely más lényeges körülményt (a Büntető törvénykönyv 365. § (1) bek.). A bíróságnak további egyszerü bizonyítást is le kell folytatnia, ha a büntetőeljárásban a bíróság előtt fekvő bizonyítékok nem elegendőek a kártérítési igény megfelelő elbírálásához (a Büntetőeljárási törvénykönyv 366. § (2) bek.). Az osztrák büntetőeljárásban és a cselekmény következtében elszenvedett és a büntetőeljárás keretében érvényesített kártérítési igényekre (Adhäsionsverfahren) a nyomozati elv vonatkozik, ami annyit jelent, hogy a bíróságnak hivatalból kell a tényállást megállapítania ahelyett, hogy a felekre hárulna a bizonyítás. Ezért a bíróságra hárul a kártérítés kérdésében való döntéshozatalhoz szükséges bizonyítás lefolytatása.

\section{Németország}

Az igény érvényesítésére szolgáló kérelemnek megfelelö bizonyítékokat kell tartalmaznia. Nem jelent azonban hátrányt a bizonyítékok megadásának hiánya sem, mivel a bíróságnak hivatalból az igazság kiderítésére kell törekednie, és ennek a döntés szempontjából jelentőséggel bíró minden tényre és bizonyítékra ki kell terjednie.

\section{Egyesült Királyság}

- Anglia és Wales

A bíróság az általa fontosnak ítélt kérdésekben tájékoztatást kér a sértettől.

- Skócia

A bíróság az általa fontosnak ítélt információkat vagy bizonyítékokat bekéri az ügyésztől.

- Észak-Írország

A bíróság az általa szükségesnek ítélt kérdésekben tájékoztatást kér a sértettől. Az ilyen információt rendszerint a bünüldöző hatóság nyomozza ki, mielött az ügyet a bíróság elé terjesztené. Bizonyos esetekben a sértettet felkéri, hogy eskü alatt tegyen tanúvallomást.

\section{Franciaország}

A sértettnek be kell mutatnia az igényét igazoló iratokat: orvosi igazolás, munkabeszüntetés és keresetkiesés, számlák, költségjegyzékek stb.

Sérülés esetén a bíróság szakértői vizsgálatot rendelhet el, hogy a sérülés nagyságát hivatalból vagy a sértett kérelmére megállapítsák. A szakértői vizsgálat eredményének megszületéséig a sértett előleg folyósítását kérheti (kártérítési előleg).

\section{Magyarország}

A polgári jogi igényt megalapozó kárt a magánfélnek kell bizonyítania. Ennek érdekében csatolni kell azokat a bizonyítékokat, amelyekre hivatkozik. A magánfél az eljárás során a vádlotthoz, tanúhoz - bírói engedéllyel - közvetlenül intézhet kérdéseket. 


\section{A bíróság által megítélt kártérítési igény végrehajtásához nyújtott speciális segítség Ausztria}

A büncselekmények áldozatai részére az osztrák Igazságügyi Minisztérium által támogatott és a jogi és lelki segítségnyújtásra és tanácsadásra is kiterjedő eljárási segítségnyújtást igény esetén ajánlják fel a büntetőeljárás teljes időtartama alatt, annak befejeződéséig. A büncselekmények áldozatainak e támogatása nem terjed ki a későbbi polgári ügyre vagy a megítélt kártérítés végrehajtására (végrehajtási eljárás).

Meg kell azonban jegyezni, hogy a végrehajtási eljárások során a bíróság általában tárgyalás tartása nélkül hozza meg döntését, emiatt alapjában nincsen lehetőség a büncselekmény áldozatának kikérdezésére. Azon néhány esetben, amelyben a törvény kihallgatást ír elö, ez történhet szóban vagy írásbeli nyilatkozatban is. Az ilyen szóbeli kihallgatás lefolytatható - a felhatalmazott képviselő és a hatósági tanú jelenlétében - a többi kikérdezendő személy egyidejü jelenléte nélkül is. Ez kizárja az összeütközést az áldozat és az elkövető között.

\section{Németország}

Nem jár, nincs ilyen külön szolgáltatás.

\section{Egyesült Királyság}

- Anglia és Wales

A bíróság számos intézkedést hozhat, ha az elkövető nem teljesíti fizetési kötelezettségét. Például a bíróság elrendelheti, hogy az elkövető béréből vagy szociális biztonsági ellátásaiból vonják le a büntetés összegét. Végső esetben a bíróság börtönbüntetésre is ítélheti a fizetést elmulasztó elkövetőt. Ez után az intézkedés után a pénzbüntetés hatályát veszti, hiszen a bíróság további szankciókat érvényesen már nem alkalmazhat.

\section{- Skócia}

A kártérítési végzés kimondja, hogy a kifizetést a bíróságon keresztül kell lebonyolítani. Rendszerint a bíróság ugyanolyan hatáskörrel rendelkezik a kártérítési összeg kifizetésének végrehajtatásában, mint a bírságok beszedésében. E hatáskör keretében egyebek mellett a bíróság részletfizetést rendelhet el, a végzést az elkövető lakóhelye szerinti bíróság elé utalhatja végrehajtásra, illetve, amennyiben ez szükséges, az elkövetőt ismételten előállíttathatja, hogy a bíróság előtt indokolja a kifizetés elmulasztását, indokolt esetben pedig meghatározott idejü őrizetbe vételt vagy börtönbüntetést róhat ki alternatív büntetésül.

- Észak-Írország

Igen. Amennyiben a kártérítésre kötelezett személy nem fizeti meg az elrendelt kártérítés összegét, és részletfizetést sem teljesít, a bíróság az alábbiak kibocsátása révén hajtathatja végre döntését:

- foglalási végzés a kifizetetlen összeg erejéig; vagy

- szabadságvesztést elrendelő végzés; vagy

- megfelelő foglalás hiányában szabadságvesztést elrendelő végzés.

A két utóbb említett intézkedés után a pénzbüntetés hatályát veszti, hiszen a bíróság további szankciókat érvényesen már nem alkalmazhat.

\section{Franciaország}

Az áldozatsegítő szervezetek a leggyakrabban az áldozatok figyelemmel kísérését biztosítják a büntetés kihirdetése után, illetve segítséget nyújtanak abban, hogy az áldozat eligazodjon az eljárások menetében. 
Másfelől, ha az elkövetőt olyan büntetésre ítélik, amely kárenyhítési kötelezettséget tartalmaz a sértett javára, a sértettel pártfogó ügyvéd veszi fel a kapcsolatot, hogy a visszatérítés módozatait áttekintsék.

\section{Magyarország}

A bíróság az ítéletnek a polgári jogi igényre vonatkozó részét nem nyilváníthatja előzetesen végrehajthatónak.

A magánfél indítványára a polgári jogi igény biztosítására zár alá vételnek van helye. A zár alá vétel kiterjedhet olyan vagyontárgyakra is, amelyek nincsenek a büncselekménnyel összefüggésben. A jogerősen megítélt polgári jogi igény érvényesítésre vonatkozó részletes szabályokat a bírósági végrehajtásról szóló 1994. évi LIII. törvény tartalmaz.

\section{B.) AZ ÁLlAM, ILLETVE VALAMELY ÁLlAMI SZERV ÁLTAL NYÚJTOTT KÁRENYHÍTÉS}

\section{Az állam vagy az állami szervek által nyújtott kárenyhítés Ausztria}

Az állami támogatást a büncselekmények áldozatainak történő segítségnyújtásról szóló, 1972 . július 9-i szövetségi törvény (Hivatalos Osztrák Szövetségi Közlöny, 1972/288) alapján nyújtják (a továbbiakban: a büncselekmények áldozatairól szóló törvény Verbrechensopfergesetz - VOG) a hat évnél hosszabb szabadságvesztéssel fenyegetett, szándékos, jogellenes, testi sértéssel vagy egészségkárosodással járó cselekmények esetén.

\section{Németország}

Az áldozatok kártalanításáról szóló törvény (Opferentschädigungsgesetz - OEG, 1976. május 11.) alapján eröszakos büncselekmények miatt lehet kártérítést kérni.

\section{Egyesült Királyság}

- Anglia és Wales

Igen, az állam létrehozott egy olyan rendszert, amely lehetővé teszi kártérítés fizetését az erőszakos büncselekmény következtében testi és/vagy lelki sérelmet szenvedett személyek számára. A rendszert a Bűnügyi Kárenyhítési Igazgatóság (Criminal Injuries Compensation Authority (CICA)) kezeli.

- Skócia

Ugyanaz a szabály érvényesül, mint Angliában és Walesben.

- Észak-Írország

Igen, az állam létrehozott egy olyan rendszert, amely lehetővé teszi kártérítés fizetését az erőszakos büncselekmény következtében testi és/vagy lelki sérelmet szenvedett személyek számára.

Az Észak-Írországi Bűnügyi Kárenyhítési Rendszert (Northern Ireland Criminal Injuries Tariff Compensation Scheme) (2002) a Kárenyhítési Hivatal („Hivatal”) kezeli, és valamennyi olyan sérelemre kiterjed, amelyet 2002. május 2-ával bezárólag ÉszakÍrországban szenvedtek el.

\section{Franciaország}

Az 1990. július 6-i törvény a nemzeti szolidaritáson alapuló autonóm kárenyhítési rendszert vezetett be a sértettek javára. A törvény a személyek elleni vétségekből eredő károk teljes kártérítésének elvét szögezi le. A kérelmezőnek ahhoz az Elsőfokú Bíróság mellett felállított 
Büncselekmények Áldozatainak Kárenyhítési Bizottságához (Commission d’Indemnisation des Victimes d'Infractions, C.I.V.I.) kell fordulnia, amely a lakóhelyéhez vagy az elkövetés helyéhez a legközelebb található, és a részére kiutalt összegeket a Terrorcselekmények és Egyéb Büncselekmények Áldozatainak Garanciaalapja folyósítja, amely az eljárásban félként vesz részt, és amely visszkereseti igényt támaszthat az elkövetővel szemben.

A megtérítendő kárnak büncselekményre utaló szándékos vagy nem szándékos cselekményből kell erednie. A terrorcselekmények, a közlekedési és vadászati balesetek vagy a kártékony állatok elpusztítására irányuló cselekmények azonban nem az 1990. július 6-i törvény, hanem más kárenyhítési rendszerek alá tartoznak.

\section{Magyarország}

A büncselekmények áldozatainak segítéséről és az állami kárenyhítésröl szóló 2005. évi CXXXV. törvény értelmében 2006. január 01-től kárenyhítés az Igazságügyi Hivatal Áldozatsegítő Szolgálatától kérhető.

\section{A kárenyhítésre alapot adó bűncselekmények köre Ausztria}

Az állami támogatás vonatkozásában a meghatározó tényező az, hogy a sértett jogellenes és szándékos, hat hónapnál hosszabb idejü szabadságvesztéssel büntetendő büncselekmény áldozata legyen.

\section{Németország}

A kártérítés a szándékos, jogellenes támadások, valamint az erőszak alkalmazásával elkövetett büncselekmények áldozatainak is rendelkezésére áll. Az olyan tettleges támadás áldozata is igényjogosult, aki egy támadás során közveszélyes eszközök által, például egy robbanásban, más személy támadása folytán vagy egy támadás elhárítása során károsodott. A nemi erkölcs elleni büncselekmények áldozatai ugyancsak kérhetnek kártérítést.

Nem jár kártérítés azon büncselekmények vonatkozásában, amelyek nem testi épség elleni támadásként jelennek meg, ilyen például a betörés vagy csalás.

\section{Egyesült Királyság}

- Anglia és Wales

Kártérítésre az a sértett jogosult, akivel szemben erőszakos bűncselekményt követtek el. A törvény ugyan nem tartalmazza e fogalom meghatározását, de rendszerint a jogtalan támadás, a sértett megsebesítése, illetve a szexuális büncselekmények tartoznak ide. Bizonyos esetekben az erőszakkal való fenyegetés szintén erőszakos büncselekménynek tekinthető.

- Skócia

Ugyanaz a szabály érvényesül, mint Angliában és Walesben.

- Észak-Írország

Kártérítésre az a sértett jogosult, akivel szemben erőszakos büncselekményt (ideértve a gyújtogatást és a mérgezést is) követtek el. A törvény ugyan nem tartalmazza az ,erőszakos büncselekmény" fogalmának meghatározását, de rendszerint testi sértés valamely személyt ért jogtalan támadást (például a sértett megsebesítése vagy a szexuális büncselekmény) jelent. Bizonyos esetekben az erőszakkal való fenyegetés szintén erőszakos büncselekménynek tekinthető. A személyt ért sérelem az alábbiakat foglalja magában: testi sérelem és veszteség, halált okozó sérülés és lelki sérelem (azaz munkaképtelenséggel járó elmebetegség, amit pszichiátriai diagnózis támaszt alá). 


\section{Franciaország}

Az elszenvedett károk teljes körü kárenyhítése a személy ellen irányuló súlyos büncselekményt és nemi erőszakot elszenvedett sértettekre korlátozódik; a személy ellen irányuló enyhe büncselekmények és bizonyos vagyon elleni büncselekmények sértettjei maximált összegủ szolidaritási támogatást kaphatnak.

\section{Magyarország}

Kárenyhítésre csak az a természetes személy áldozat jogosult, akinek sérelmére szándékos, személy elleni erőszakos büncselekményt követtek el.

\section{A kárenyhítésre lehetőséget adó sérelmek típusai \\ Ausztria}

A szabály az, hogy a büncselekménynek tényleges testi sérülését vagy az áldozat egészségének károsodását kellett előidéznie.

A keresőképessége csökkenése miatt a támogatást a keresetkiesés vonatkozásában csak akkor fogják megadni, ha ez az állapot legalább hat hónapig fennmarad, vagy ha a Büntető törvénykönyvben megállapított súlyos testi sérülés áll fenn.

\section{Németország}

A kártérítési igény előterjesztésének feltétele a tettleges támadás következményeként testi vagy lelki sérelem bekövetkezése. Havi járadékfizetés megítélésére csak tartós egészségkárosodás megléte esetén kerül sor. Tisztán vagyoni károkért nem biztosított a kártérítés.

\section{Egyesült Királyság}

- Anglia és Wales

Azok a sértettek jogosultak kártérítésre, akik fizikai vagy lelki sérelmet szenvedtek az esemény következtében. Azonban a sértett csak akkor jogosult a minimális kártérítésre, ha fizikai vagy lelki sérülése kellően súlyos.

- Skócia

Ugyanaz a szabály érvényesül, mint Angliában és Walesben.

- Észak-Írország

Azok a sértettek jogosultak kártérítésre, akik olyan mérvü fizikai és/vagy lelki sérelmet szenvedtek, hogy az Észak-Írországi Bünügyi Kárenyhítési Rendszerben érvényes díjsávokba besorolható.

\section{Franciaország}

A C.I.V.I.-nél kétféle típusú kár esetében kerülhet sor kárenyhítésre:

- a személy elleni súlyos büncselekményeket a büntetőeljárási kódex 706-3. cikke határozza meg. A büncselekményre utaló cselekmény a halált, állandó munkaképtelenséget, egy hónapos vagy azt meghaladó teljes munkaképtelenséget okozó, illetve a nemi büncselekménynek minősülő cselekmény.

- a személy ellen irányuló enyhe büncselekmények és a vagyon elleni büncselekmények a büntetőeljárási kódex 706-14. cikke alá tartoznak. Ennek megfelelően a lopás, a szélhámosság, a bizalommal való visszaélés, a zsarolás, illetve a vagyonrongálás, vandalizmus vagy vagyonkárosítás sértettjei, valamint az egy hónapot meg nem haladó teljes munkaképtelenséget okozó személy elleni büncselekmény sértettjei - meghatározott 
feltételek mellett - részesülhetnek kárenyhítésben. Igazolniuk kell, hogy az általuk elszenvedett kár tényleges és megfelelő enyhítését más úton (biztosítás stb.) nem tudják elérni, igazolniuk kell az ebből következő súlyos anyagi helyzetet vagy lelki állapotot, valamint igazolniuk kell azt is, hogy havi jövedelmük nem éri a megállapított összeghatárt.

\section{Magyarország}

Kárenyhítés csak akkor fizethetö, ha az arra alapot adó büncselekmény következményeként a sértett meghalt, vagy testi épsége, egészsége súlyosan károsodott.

\section{A kárenyhítés iránti igény átszállása}

\section{Ausztria}

A VOG alapján a túlélő eltartottak ugyancsak jogosultak kártérítésre.

\section{Németország}

Kártérítési igénye lehet az áldozat házastársának, gyermekeinek és különleges esetekben a szüleinek is. Az elvált házastárs és a nagyszülök akkor kaphatnak kártérítést, ha öket az áldozat tartja vagy tartotta el.

\section{Egyesült Királyság}

- Anglia és Wales

Amennyiben a sértett büncselekmény következtében hal meg, eltartott hozzátartozója vagy családtagja jogosult lehet halált okozó testi sértés miatt kártérítésre. A kártérítésre azok az eltartott hozzátartozók és családtagok jogosultak, akik a sértett halála idején a sértettel az alábbi kapcsolatban álltak:

- férj vagy feleség

- tartós élettársi kapcsolat (nemtől függetlenül)

- szülő

- gyermek (kortól függetlenül)

- elvált férj vagy feleség (ha az elhunyt pénzügyileg támogatta)

- Skócia

Ugyanaz a szabály érvényesül, mint Angliában és Walesben.

- Észak-Írország

Ugyanaz a szabály érvényesül, mint Angliában és Walesben.

\section{Franciaország}

A kárenyhítésre való jog a büncselekmény közvetlen sértettje és annak jogosultjai számára biztosított.

\section{Magyarország}

Kárenyhítésre jogosult a sértetten kívül az a természetes személy is, aki a szándékos, személy elleni erőszakos büncselekmény következtében testi épségében, egészségében súlyosan károsodott sértettnek, vagy meghalt személynek az elkövetés időpontjában egy háztartásban élő egyenes ági rokona, örökbefogadója vagy nevelöszülője, örökbe fogadott vagy nevelt gyermeke, házastársa, élettársa, továbbá akinek eltartására a sértett jogszabály, végrehajtható bírósági, illetőleg hatósági határozat vagy érvényes szerződés alapján köteles volt. 


\section{Az állampolgárság és a lakóhely jelentősége a kárenyhítési igény érvényesítésében Ausztria}

Az osztrák állampolgárokat a támogatás attól függetlenül megilleti, hogy a büncselekmény hol történt. Továbbá az Európai Gazdasági Térség polgárai jogosultak kártérítés igénylésére az Ausztriában elszenvedett károsodásért. Az Ausztrián kívül elszenvedett sérülések vonatkozásában a meghatározó tényező az, hogy - összhangban az Európai Gazdasági Térségröl szóló megállapodásban meghatározott letelepedési és mozgásszabadsággal - az állandó lakóhelynek Ausztrián belül kell lennie.

\section{Németország}

Kártérítési igényt a német állampolgársággal, valamint a Németországban szokásos tartózkodási hellyel rendelkezők nyújthatnak be. Az Európai Unió tagállamainak állampolgárai és a Németországban három évnél hosszabb ideje jogszerüen tartózkodó külföldiek teljes mértékben élvezik e szolgáltatást. A három évnél rövidebb ideje jogszerüen Németországban tartózkodók jövedelemtől nem függő szolgáltatásokban részesülnek, vagy végleges kiutazásuk esetén végkielégítést kapnak. A látogatók és turisták súlyos károsodás esetén egyszeri, méltányossági szolgáltatásban részesülnek.

\section{Egyesült Királyság}

- Anglia és Wales

Nem, amennyiben az esemény Angliában, Walesben vagy Skóciában következett be. ÉszakÍrországra már más szabályok vonatkoznak. Érdeklődés esetén a CICA ad tájékoztatást arról, hogy valamely kérelem befogadható-e.

\section{- Skócia}

Ugyanaz a szabály érvényesül, mint Angliában és Walesben.

- Észak-Írország

Az eseménynek Észak-Írországban kell bekövetkeznie. A Kárenyhítési Hivatal ad felvilágosítást arról, hogy valamely kérelem befogadható-e.

\section{Franciaország}

$\mathrm{Az}$ állampolgárság tekintetében a sértettnek csakugyan eleget kell tennie bizonyos feltételeknek. Ennek megfelelően a következők kérhetnek kárenyhítést:

- a francia állampolgárságú sértettek függetlenül attól, hogy a cselekményt Franciaországban vagy külföldön követték el,

- az Európai Közösség tagállamainak állampolgárai vagy olyan állam állampolgárai, amely viszonossági megállapodást kötött Franciaországgal (az erőszakos büncselekmények kárenyhítéséről szóló európai egyezmény részes államainak állampolgárai), ha a cselekményt francia területen követték el

- francia területen elkövetett cselekmény esetében azok a külföldi sértettek, akik nem az Európai Közösség valamely tagállamának állampolgárai, és akik a cselekmény vagy a kérelem időpontjában jogszerüen tartózkodnak Franciaországban a nemzetközi szerződésekre vagy egyezményekre is figyelemmel.

\section{Magyarország}

Kárenyhítést kaphat a magyar állampolgár, az Európai Unió bármely tagállamának állampolgára, a Magyar Köztársaság területén jogszerűen tartózkodó hontalan személy, az emberkereskedelem áldozata, az, aki az állampolgársága szerinti államnak a Magyar Köztársasággal kötött nemzetközi megállapodása vagy viszonosság alapján erre jogosult, továbbá az a személy, aki az Európai Unió valamely tagállamában lakóhellyel vagy szokásos 
és jogszerü tartózkodási hellyel rendelkezik. Kárenyhítésben részesíthető az áldozat akkor is, ha Magyarországon tartózkodási vagy bevándorlási engedéllyel rendelkezik.

\section{A kárenyhítési igény érvényesítésének lehetősége és feltételei, amennyiben a sértett tartózkodási helyéül szolgáló tagállamban vált áldozattá Ausztria}

A fent meghatározottak szerint egyes körülmények fennállása esetén a külföldön elkövetett büncselekmények vonatkozásában is fizetnek kártérítést.

\section{Németország}

Az erőszakos büncselekmények áldozatainak kártalanításáról szóló törvény mögött az az alapgondolat áll, hogy a tettleges támadás áldozatának megtérítési igénye keletkezik az állammal szemben, amely őt minden erőfeszítés ellenére sem tudta megvédeni. Mivel az eröszakos büncselekmények áldozatainak kártalanításáról szóló törvény a területi elven nyugszik, kártérítést csak akkor ítélnek meg, ha a tettleges támadás a törvény hatálya alá tartozó területen történt.

\section{Egyesült Királyság}

- Anglia és Wales

Abban az országban, ahol a sértett a sérelmet elszenvedte, valószínüleg rendelkezésre áll egy hasonló kártérítési rendszer.

- Skócia

Ugyanaz a szabály érvényesül, mint Angliában és Walesben.

- Észak-Írország

Ugyanaz a szabály érvényesül, mint Angliában és Walesben.

\section{Franciaország}

A francia állampolgárságú sértettek akkor is folyamodhatnak kárenyhítésért a Büncselekmények Áldozatainak Kárenyhítési Bizottságaihoz, ha külföldön váltak áldozattá, és ezt ugyanolyan feltételek mellett tehetik meg, mintha a cselekményt Franciaországban követték volna el.

\section{Magyarország}

$\mathrm{Az}$ Európai Unió bármely tagállamában benyújtható a kérelem, ha a bűncselekményt Magyarországon követték el. Ilyen esetben akkor fizethető kárenyhítés, ha a kérelmező megfelel a büncselekmények áldozatainak segítéséről és az állami kárenyhítésről szóló 2005. évi CXXXV. törvény által támasztott követelményeknek.

\section{A rendőrségi feljelentés szerepe a kárigény érvényesítésében}

\section{Ausztria}

A kérelmezők kötelesek közremüködni a büncselekmény felderítésében és az elkövető kézre kerítésében. Nem jár a támogatás, ha az áldozat szándékosan mulasztja el a segítségnyújtást.

\section{Németország}

Az áldozatnak minden tőle telhetőt meg kell tennie a cselekmény felderítésére és a tettes kézre kerítésére, ide tartozik különösen az illetékes hatóságnál (rendőrségnél vagy ügyészségnél) a feljelentés megtétele, a büntetőeljárás megindítása céljából. Persze különleges esetekben ( $\mathrm{pl}$. nemi erkölcs elleni büncselekmény, családon belül elkövetett büncselekmények) a feljelentési kötelezettségtől kivételesen eltekintenek. 


\section{Egyesült Királyság}

- Anglia és Wales

Alapvető, hogy a sértett a lehető legrövidebb időn belül bejelentse a büncselekményt a rendőrségnek, és hivatalos feljelentést tegyen. A CICA kivételesen eltekinthet ettől olyan esetekben, amikor a sérelmet például iskolában, börtönben, idősek otthonában vagy pszichiátriai intézetben szenvedték el, feltéve, hogy az eseményt illetékes személynek bejelentették, és a sértett hozzájárult annak hivatalos kivizsgálásához.

- Skócia

Alapvető, hogy a sértett a lehető legrövidebb időn belül bejelentse a büncselekményt a rendörségnek, és hivatalos feljelentést tegyen. A CICA kivételesen eltekinthet ettöl olyan esetekben, amikor a sérelmet például iskolában, börtönben, idősek otthonában vagy pszichiátriai intézetben szenvedték el, feltéve, hogy az eseményt illetékes személynek bejelentették, és a sértett hozzájárult annak hivatalos kivizsgálásához.

- Észak-Írország

Amennyiben a sértett nem jelenti be a sérelem körülményeit a rendőrségnek, és mulasztását nem tudja hitelt érdemlően indokolni, kártérítési igényét szinte bizonyosan visszautasítják.

\section{Franciaország}

A Büncselekmények Áldozatainak Kárenyhítési Bizottságához benyújtott kárenyhítés iránti kérelemhez a kérelmezőnek csatolnia kell a panasz benyújtásáról kapott átvételi elismervényt és a büntetőeljárással kapcsolatban rendelkezésére álló összes iratot.

\section{Magyarország}

Igen, szükség van a feljelentésre. Nem teljesíthető ugyanis a kárenyhítési kérelem, ha nincs folyamatban büntetőeljárás.

\section{A kárigény érvényesítésének lehetősége és a büntetőeljárás viszonya Ausztria}

A VOG alapján a kérelmeket a rendőrségi nyomozás vagy a büntetőeljárás állásától függetlenül elö lehet terjeszteni.

\section{Németország}

A tartományokban az erőszakos bűncselekmények áldozatainak kártalanításáról szóló törvény végrehajtására illetékes nyugellátási hivatalok a rendőrségi, ügyészségi, bírósági vizsgálatok eredményeitől függetlenül saját hatáskörben dönthetnek az áldozat kártalanítására vonatkozó kérelemről. Ezért az ilyen kérelmet a rendőrségi vagy ügyészségi vizsgálati eljárás megindításától vagy lefolyásától függetlenül, a károsodásra vezető eseményt követően a lehető leghamarabb elő kell terjeszteni.

\section{Egyesült Királyság}

- Anglia és Wales

A CICA rendszerint megvárja a tárgyalás lezárását, mielőtt meghozná döntését.

- Skócia

A CICA azonban rendszerint megvárja a tárgyalás lezárását, mielőtt meghozná döntését.

- Észak-Írország 
A Hivatal azonban rendszerint megvárja a büntetőeljárás végkimenetelét.

\section{Franciaország}

A Büncselekmények Áldozatainak Kárenyhítési Bizottságát többek között azért hozták létre, hogy az áldozatnak ne kelljen megvárnia a büntetőper kimenetelét.

\section{Magyarország}

Nem kell megvárni, a kérelem a büntetőeljárás alatt is benyújtható.

\section{Van-e kötelező sorrend a kárigény érvényesítésében?}

\section{Ausztria}

A VOG alapján történő állami támogatás elnyerése érdekében nem kell a tettest elöször a polgári jog alapján perelni.

Azonban a VOG alapján történő állami támogatás összegének kiszámításakor számításba kell venni az elkövető által már teljesített minden kártérítési kifizetést.

\section{Németország}

A szociális kártalanítási jog részeként az erőszakos büncselekmények áldozatainak kártalanításáról szóló törvényböl eredő igény független a tettessel szemben esetlegesen támasztott kártérítési igénytől. Az elkövető általi megfizetés igénybevétele vonatkozásában az áldozatnak az elkövetővel szembeni igényei az állami költségviselőre szállnak át, az áldozatok kártalanításáról szóló törvény elöírásai alapján megítélt mértékben.

\section{Egyesült Királyság}

- Anglia és Wales

Nincs, azonban az elkövető által a sértett részére fizetett kártérítés összegét a CICA által megítélt összegből levonják.

- Skócia

Ugyanaz a szabály érvényesül, mint Angliában és Walesben.

- Észak-Írország

Ugyanaz a szabály érvényesül, mint Angliában és Walesben.

\section{Franciaország}

Nem, az eljárások egymástól függetlenek, és a Bűncselekmények Áldozatainak Kárenyhítési Bizottságát nem köti a más bíróság által korábban megítélt kártérítések összege.

\section{Magyarország}

Nem, nincs erre szükség.

10. A felderítés vagy a bizonyítás problémái és a kárigény érvényesítésének lehetősége. Mit kell bizonyítania a sértettnek?

\section{Ausztria}

Állami támogatás olyan esetben is adható, ha az elkövető ismeretlen, feltéve, hogy minden valószínüséggel a törvényben meghatározott kritériumok szerinti büncselekményt követték el.

\section{Németország}


A kártérítés megítélése teljesen független a tettes büntetőjogi felelősségre vonásától. A kérelmezőnek - mint a szociális jogban mindenütt - az áldozatok kártalanítása terén is bizonyítania kell a kérelmet megalapozó tényeket, különösen az erőszakos büncselekménynek a sérelmére történt elkövetését és az azzal okozott egészségkárosodást. A kérelmező javára bizonyításkönnyítés érvényesül különösen azokban az esetekben, amelyekben a tettes ismeretlen, vagy más bizonyítékok nem állnak rendelkezésre.

\section{Egyesült Királyság}

- Anglia és Wales

Amint a CICA átveszi az igénylőlapot, felveszi a kapcsolatot a rendőrséggel, kórházakkal, orvosokkal és minden olyan szervezettel, amely a kártérítési igénnyel kapcsolatban tájékoztatást adhat. Az igénylőlap egyik rovatában a sértett hozzájárulását adhatja az ilyen jellegü kapcsolatfelvételhez.

- Skócia

Ugyanaz a szabály érvényesül, mint Angliában és Walesben.

- Észak-Írország

A sértett hozzájárulásával a Kárenyhítési Hivatal felveszi a kapcsolatot a rendőrséggel, kórházakkal, orvosokkal, a munkáltatóval vagy bárki mással, aki segítséget nyújthat a kártérítési igény jogosságának bizonyításához.

\section{Franciaország}

A Büncselekmények Áldozatainak Kárenyhítési Bizottsága előtti kárenyhítési eljárás akkor is lehetséges, ha az elkövető ellen nincs büntetöítélet. Az eljárás elindításához egyszerúen elegendő az a tény, hogy valaki a büntetőeljárási kódex 706-3. vagy 706-14. cikke szerinti büncselekmény következtében kárt szenvedett.

\section{Magyarország}

Akkor is jár kárenyhítés, ha nem azonosítják az elkövetőt.

Abban az esetben, ha a vádlottat felmentik, csak akkor jár kárenyhítés, ha a felmentésére gyermekkor, kóros elmeállapot, kényszer vagy fenyegetés, tévedés, jogos védelem, végszükség vagy elöljáró parancsa, az elkövető halála, elévülés, kegyelem, a cselekmény társadalomra veszélyességének megszünése vagy csekéllyé válása, vagy a Büntető Törvénykönyvről szóló 1978. évi IV. törvényben meghatározott egyéb ok miatt került sor.

\section{A kártérítési igény benyújtási lehetősége és az elévülés Ausztria}

Az elkövetés időpontjától számított hat hónap, valamint két év az a határidő, amelyen belül az egyedi támogatás iránti kérelmeket be lehet terjeszteni. A később előterjesztett kérelmekre a támogatást rendszerint a kérelem előterjesztését követő hónaptól kezdődően adják meg.

\section{Németország}

Nincs határidőhöz kötve a kártérítési kérelem benyújtása. A szolgáltatásokat elvileg a kérelem benyújtásának hónapjától kezdődően fizetik. Azok azonban a kérelem benyújtása előtti időre is megítélhetőek, ha a kérelmet a büncselekmény elkövetésétől számított egy éven belül terjesztették elö.

\section{Egyesült Királyság}

- Anglia és Wales 
A CICA rendszerint csak azokat a kérelmeket bírálhatja el, amelyeket az esemény bekövetkeztétöl számított két éven belül kap kézhez. Indokolt esetben és az igazságszolgáltatás érdekében a CICA kivételesen eltekinthet a fenti határidőtől. Az ilyen esetek azonban ritkák.

- Skócia

Ugyanaz a szabály érvényesül, mint Angliában és Walesben.

- Észak-Írország

A kérelmet a sérelmet okozó esemény bekövetkeztétől számított két éven belül kell benyújtani a Kárenyhítési Hivatalhoz. Indokolt esetben és az igazságszolgáltatás érdekében a fenti határidőtől el lehet tekinteni.

\section{Franciaország}

A kárenyhítés iránti kérelmet elévülés terhe mellett a büncselekmény időpontjától számított három éven belül, illetve amennyiben büntetőeljárás indult, az utolsó bírói döntést követő év folyamán kell benyújtani. Ha a kérelmezőnek nem állt módjában, hogy jogait a megszabott határidőn belül érvényesítse, vagy ha a kára súlyosbodott, illetve bármilyen jogos indok esetén a Bűncselekmények Áldozatainak Kárenyhítési Bizottsága módosíthatja a jogvesztő határidőt.

\section{Magyarország}

A kárenyhítési kérelmet a büncselekmény elkövetését követő három hónapon belül lehet benyújtani. Ez alól a szabály alól három kivétel van:

- Ha a kérelem elöterjesztése elháríthatatlan akadályba ütközik, a kérelmet az akadály megszünését követő három hónapon belül lehet előterjeszteni.

- Ha egy korábban államigazgatási eljárásban vizsgált cselekményről később derül ki, hogy az büncselekmény, a kérelmet a büntetőeljárás megindítását követő három hónapon belül lehet elöterjeszteni.

- Ha a büncselekmény elkövetését követően később derül ki, hogy az áldozat testi épségének, egészségének súlyos károsodása és a büncselekmény között ok-okozati összefüggés áll fenn, a kérelmet a tudomásra jutástól számított három hónapon belül lehet elöterjeszteni.

\section{A kárenyhítésnél figyelembe vehető károk köre}

\section{Ausztria}

A VOG a következő támogatási formákat szabályozza:

- a keresetveszteség vagy kieső tartásdíj megtérítése

- orvosi ellátás

- ortopéd kezelés

- rehabilitáció

- gondozási vagy vaksági járadék

- temetési költségek megtérítése.

\section{Németország}

Az áldozatok kártalanításáról szóló törvény alapján a szolgáltatások az elszenvedett károk egészségügyi vagy gazdasági következményeinek ellentételezésére szolgálnak. A nemvagyoni károkat nem térítik meg.

\section{Egyesült Királyság}


- Anglia és Wales

A rendszer az alábbi esetekben engedélyezi pénzbeli kártérítés kifizetését:

- az erőszakos büncselekmény által okozott testi és lelki sérelem elismeréseként;

- bizonyos körülmények között az erőszakos büncselekmény által okozott múltbeli vagy jövőbeni keresetkiesés vagy különleges kiadások kártérítéseként;

- eröszakos büncselekmény következtében elhunyt közvetlen családtag után, ideértve néhány esetben a meggyilkolt személy keresetkiesésének megtérítését.

- Skócia

Ugyanaz a szabály érvényesül, mint Angliában és Walesben.

- Észak-Írország

Ugyanaz a szabály érvényesül, mint Angliában és Walesben.

\section{Franciaország}

A büntetőeljárási kódex 706-3. cikke értelmében minden személy elleni bűncselekményből eredő kárra nyújtható kárenyhítés, függetlenül attól, hogy a kár vagyoni jellegü-e vagy sem. Különösen érvényes ez a szabad foglalkozásból eredő jövedelem támadás általi csökkenéséből keletkező kárra, az elrabolt vagy megerőszakolt gyermek szülei által elszenvedett aggodalomból és gyötrelmekből eredő kárra, a büncselekmény következtében elhalálozott áldozat jogosultjai által elszenvedett állandó részleges, illetve teljes munkaképtelenségből eredő kárra, illetve azon kiskorú gazdasági kárára, akinek büncselekmény következtében elhalálozott anyja biztosította megélhetését és oktatását.

A tisztán anyagi kár nem tartozik a büntetőeljárási kódexben meghatározottak közé. Következésképpen elutasítják például a ruházati kárra, illetve az ékszer elvesztéséből vagy megrongálásából eredő kárra irányuló kárenyhítési kérelmeket.

\section{Magyarország}

A kár megállapítása érdekében a kérelemben meg kell jelölni a büncselekmény következtében elszenvedett vagyoni kár összegét, a bizonyítható jövedelem kiesését, illetve minden olyan költséget, amely a büncselekmény miatt keltezett, illetve a büncselekménnyel okozott kár megszüntetése érdekében merült fel.

\section{A kártérítési összeg kiszámítása}

\section{Ausztria}

Az állami támogatások föként a polgári jogi szempontokhoz (a kártérítésre vonatkozó polgári jogi szabályokhoz) igazodnak.

A keresetkiesés vagy kieső tartásdíj megtérítése miatti kártérítés megítélésekor a cselekmény eredményeként bekövetkezett jövedelem-kiesést egy rögzített felső mértékig térítik meg. A támogatás gondozási vagy vaksági járadék alakjában történő megadásakor az ezen felüli gondozási költségek egy rögzített arányú összegét térítik meg.

\section{Németország}

A büncselekmények áldozatai részesülnek a betegellátásnak az egészség helyreállításához vagy javításához szükséges intézkedéseiben (beleértve például az egészségügyi vagy szakmai rehabilitációs intézkedéseket, ápolási szolgáltatásokat, pszichoterápiás kezelést stb.), a 
megélhetést biztosító olyan szolgáltatásokban, mint az egészségügyi és gazdasági károk ellentételezésére szolgáló tartós járadékfizetés. A lépcsőzetes járadékszolgáltatás nagysága igazodik a mindenkori egészségkárosodás mértékéhez, valamint a károsodás miatt bekövetkezett feltételezett keresetkieséshez.

\section{Egyesült Királyság}

- Anglia és Wales

A Bünügyi Kárenyhítési Rendszer (Criminal Injuries Compensation Scheme) több mint 400 sérelem leírását sorolja fel, megjelölve azt a normatív kártérítési összeget, amelyet a CICA a sértett által elszenvedett fájdalom díjaként kifizethet. Amennyiben a sértett egynél több minősített sérelmet szenved el, a megítélt kártérítés a legsúlyosabb sérelem utáni díj teljes összege, kiegészítve a második legsúlyosabb sérelem utáni díj 30\%-ával, és adott esetben a harmadik legsúlyosabb sérelem utáni díj 15\%-ával. Néhány esetben további kártérítés is fizethető a keresetkiesés és a különleges kiadások után.

\section{- Skócia}

Ugyanaz a szabály érvényesül, mint Angliában és Walesben.

- Észak-Írország

Amennyiben a kérelem elfogadható, elbírálják, vajon a sérülés kellőképpen súlyos-e ahhoz, hogy a sértett jogosult legyen a tarifarendszer szerinti minimális kártérítési összegre. Amennyiben a sértett egynél több minősített sérelmet szenved el, a megítélt kártérítés a legsúlyosabb sérelem utáni díj teljes összege, kiegészítve a második legsúlyosabb sérelem utáni díj 30\%-ával, és a harmadik legsúlyosabb sérelem utáni díj 15\%-ával. Bizonyos esetekben további kártérítés fizethető keresetkiesés és a különleges kiadások után.

\section{Franciaország}

Az áldozat részére kiutalandó összegek meghatározásához a Büncselekmények Áldozatainak Kárenyhítési Bizottsága először az általános kártérítési jog szabályai szerint kiszámítja a kérelmező teljes kárát. Ennek megfelelően a kárenyhítés csökkenthető vagy elutasítható, ha az áldozat a kárral közvetlen okozati összefüggésben álló mulasztást követett el. Ezt követően a Büncselekmények Áldozatainak Kárenyhítési Bizottsága levonja a szociális biztonsági pénztárak által folyósított összegeket.

\section{Magyarország}

A kárenyhítést egy összegben vagy havi járadékként kell fizetni.

Az egyösszegü kárenyhítés mértéke:

- az alapösszeg ötszörösét meg nem haladó kár 100 százaléka,

- az alapösszeg ötszöröse és tízszerese közötti kár esetén az alapösszeg 5-szöröse,

és az alapösszeg ötszöröse feletti rész 75 százaléka,

az alapösszeg tízszeresét meghaladó kár esetén az alapösszeg 8,75-szöröse, és az alapösszeg tízszerese feletti rész 50 százaléka, de legfeljebb az alapösszeg tizenötszöröse.

A sértett büncselekmény miatt bekövetkezett keresőképtelensége esetén - ha a keresőképtelenség várhatóan a hat hónapot meghaladja - az áldozat járadék formájú kárenyhítésként a rendszeres jövedelmében bekövetkezett csökkenés részbeni enyhítését igényelheti. A járadék havi mértéke: 
- az igazolt jövedelemcsökkenés 75 százaléka, ha az áldozat 18 év alatti személy vagy mások gondozására szorul,

- az igazolt jövedelemcsökkenés 50 százaléka, ha az áldozat mások gondozására nem szorul.

\section{A kártérítés összegszerüségének korlátozása}

Ausztria

Alapjában az állami támogatás vonatkozásában nincsen felső vagy alsó határ. A keresetveszteség vagy kieső tartásdíj megtérítése vonatkozásában azonban havi jövedelmi határokat állapítottak meg.

\section{Németország}

Az egészségügyi károsodás ellentételezésére szolgáló havi járadék fizetése a károsodáshoz igazodó, meghatározott összegben történik, amelyet évente kiigazítanak. Jelenleg a legalacsonyabb fokozatban havi 118 eurót fizetnek. A gazdasági következmények ellentételezésére szolgáló minden további járadékszolgáltatás összege a büncselekmény áldozatának jövedelmi viszonyaitól függ. A havi vagy egyösszegü kártérítés vonatkozásában nincsen felső határ.

\section{Egyesült Királyság}

- Anglia és Wales

A megítélt kártérítés összege 1000 fonttól 500000 fontig terjedhet.

- Skócia

Ugyanaz a szabály érvényesül, mint Angliában és Walesben.

- Észak-Írország

Igen. A kártérítés összege legalább 1000, de legfeljebb 280000 font lehet, ami kiegészül az esetleges pénzügyi kárért fizetett kártérítéssel.

\section{Franciaország}

Nincs korlátozás. Az elv a teljes körű kárenyhítés.

\section{Magyarország}

A törvény ismeri az alapösszeg fogalmát. Az alapösszeg mértéke a tárgyévet megelőző második év - a Központi Statisztikai Hivatal által közzétett nemzetgazdasági bruttó havi átlagkeresetének 43 százaléka (2006-ban 62.651,- Ft volt).

Egyösszegü kárenyhítésként az áldozat a büncselekmény miatt bekövetkezett vagyoni kárának teljes vagy részbeni megtérítését igényelheti. Az egyösszegü kárenyhítésként legfeljebb az alapösszeg tizenötszöröse adható.

A járadék legmagasabb összege havonta az alapösszeggel egyezik meg. A járadék legfeljebb három évig adható.

\section{Az állam által nyújtott kárenyhítés és a más forrásból származó kártérítés viszonya Ausztria}

A VOG alapján járó támogatás kiszámításakor figyelembe veszik az elkövető által fizetett kártérítést, az állami járadékokat és a kötelező társadalombiztosítás alapján járó kártérítési kifizetéseket. Figyelmen kívül hagyják azonban a magán balesetbiztosításból származó kifizetéseket. 


\section{Németország}

Csak azon szolgáltatásokat veszik számításba, amit az áldozat ugyanazon károsodásra tekintettel ténylegesen megkap, és amelyeknek így ugyanazon célt kell betölteniük.

\section{Egyesült Királyság}

- Anglia és Wales

A megítélt kártérítés összegéből mindenkor levonják az azonos kárért vagy károkért kapott kárenyhítés vagy kártérítés teljes összegét. Amennyiben a CICA által kifizetett kártérítést követően a sértett más forrásból kártérítésben vagy kárenyhítésben részesül, ez utóbbi összegét vissza kell fizetnie a CICÁ-tól kapott teljes összeg erejéig.

- Skócia

Ugyanaz a szabály érvényesül, mint Angliában és Walesben.

- Észak-Írország

A megítélt kártérítés összegéből mindenkor levonják az azonos kárért vagy károkért kapott kárenyhítés vagy kártérítés teljes összegét. Amennyiben a kifizetett kártérítést követően a sértett más forrásból kártérítésben vagy kárenyhítésben részesül, ez utóbbi összegét vissza kell fizetnie a korábban kapott kártérítés teljes összegének erejéig.

\section{Franciaország}

A Büncselekmények Áldozatainak Kárenyhítési Bizottsága a kérelmező teljes kárának becsült összegéből levonja a szociális intézmények által folyósított összegeket, valamint az azonos kárért kapott vagy járó bármilyen más összeget (biztosítás stb.).

\section{Magyarország}

A járadék folyósítását meg kell szüntetni, ha a büncselekményre tekintettel az áldozat rendszeres szociális vagy nyugdíj-biztosítási ellátásra való jogosultságát megállapították, és az ellátás folyósítását megkezdték, illetve ha jogerős bírósági határozat az áldozat részére kártérítésként járadékot állapított meg, és annak folyósítását megkezdték, vagy ha a biztosító az áldozat részére járadék folyósítását kezdi meg. Az áldozat a támogatás iránti kérelmet érdemben elbíráló határozat jogerőre emelkedését követő három évig köteles visszatéríteni a pénzben nyújtott támogatást, ha a kár más forrásból részben vagy egészben megtérült, de legfeljebb a megtérülés mértékéig.

\section{A kártérítéshez jutás esélyét, és a kártérítés mértékének számítását befolyásoló körülmények Ausztria}

A VOG megállapítja azokat a szokásos körülményeket, amelyek az állami támogatás visszautasítását vagy csökkentését eredményezhetik (például a büncselekményben való részesség, garázdaság, a kár/sérelem enyhítésének elmulasztása).

\section{Németország}

A kártérítés megtagadható, ha az áldozat okozta a károsodást (vagy abban közremüködött), vagy ha egyéb okok miatt a szolgáltatások megítélése méltánytalannak tünik.

\section{Egyesült Királyság}

- Anglia és Wales 
A CICA számos tényezőt mérlegel a kárenyhítés iránti igényre vonatkozó döntés meghozatala elött. A sértettre és az esemény bekövetkeztének idejére vonatkozó adatok vizsgálata mellett azt is figyelembe veszi, hogy a sértett teljes mértékben együttmüködött-e a rendőrséggel és a CICÁ-val, szerepel-e a bűnügyi nyilvántartásban, továbbá milyen magatartást tanúsított a sérelmet okozó esemény előtt, alatt és után.

- Skócia

Ugyanaz a szabály érvényesül, mint Angliában és Walesben.

- Észak-Írország

A Kárenyhítési Hivatal számos tényezőt mérlegel a kárenyhítés iránti igényre vonatkozó döntés meghozatala előtt. A sértettre és az esemény bekövetkeztének idejére vonatkozó adatok vizsgálata mellett azt is figyelembe veszi, hogy a sértett teljes mértékben együttmüködött-e a rendőrséggel és a magával a Kárenyhítési Hivatallal. A Hivatal azt is megvizsgálja, szerepel-e a sértett a bünügyi nyilvántartásban, továbbá hogy milyen magatartást tanúsított a sérelmet okozó esemény elött, alatt és után.

\section{Franciaország}

A kárenyhítés csökkenthető vagy elutasítható, ha az áldozat a kárral közvetlen okozati összefüggésben álló mulasztást követett el.

\section{Magyarország}

Az állam általi kárenyhítés feltétele az áldozat rászorultsága. A rászorultságot a kérelmező jövedelmi viszonyai határozzák meg. Jövedelmi viszonyai alapján rászorultnak kell tekinteni azt a kérelmezőt, akinek nettó jövedelme (közös háztartásban élök esetében az egy főre jutó jövedelem) nem haladja meg az alapösszeg kétszeresét.

A törvény meghatároz kizárási okokat, amelyeket az áldozat felróható magatartása alapozza meg. Ennek megfelelően a törvény megállapít olyan cselekményeket vagy mulasztásokat, amelyek esetén még a rászoruló áldozat sem kaphat kárenyhítést. Így nem jogosult az áldozat kárenyhítésre akkor, ha kára már megtérült, vagy olyan biztosítási igényét, amelyből kárának részbeni vagy teljes megtérülése várható, nem érvényesítette; ha felróható magatartásával előidézte a büncselekményt vagy közrehatott a károkozásban; ha akár a büntetőeljárásban, akár a kárenyhítési eljárásban az eljáró hatóságokkal nem müködik együtt; ha a kárenyhítésre okot adó büncselekménnyel összefüggésben a törvényben meghatározott büncselekményt követett el.

\section{A kártérítési előleg Ausztria}

Pénzügyi szükséghelyzetben a kártérítés megelőlegezhető.

\section{Németország}

A betegápolási szolgáltatások azonnal nyújthatók, illetve azok költségei átvállalhatók. A járadékszolgáltatásoknál az előlegfizetés szabályozására nem került sor. Az áldozatok kártalanítása iránti kérelmeket azonban mindenképpen elsőbbséggel kezelik és bírálják el.

\section{Egyesült Királyság}

- Anglia és Wales

Bizonyos körülmények között felvehető előleg a kártérítésből, ezt időközi kifizetésnek nevezik. Például jövőbeni keresetkiesésre vonatkozó vagy jövőbeni orvosi vizsgálatokkal járó 
esetekben, amikor hosszabb időt vesz igénybe az ügy lezárása, a CICA mindent elkövet azért, hogy egy éven belül meghozza döntését arról, vajon a sértett jogosult-e kártérítésre. Pozitív döntés esetén a sértett ebben a szakaszban időközi kifizetésért folyamodhat. Az időközi kifizetés összegét azután a végleges kártérítés összegéből levonják.

- Skócia

Ugyanaz a szabály érvényesül, mint Angliában és Walesben.

- Észak-Írország

Lehetőség szerint a Hivatal igyekszik a kérelmeket a kártérítés egy összegben történő kifizetésével rendezni (végleges kártérítés). Bizonyos esetekben azonban időközi kifizetés is eszközölhető (például amikor az egészségi állapot tisztázásra szorul). A kifizetett összeget vagy összegeket azután a végleges kártérítés összegéből levonják.

\section{Franciaország}

A kérelmező előleg megítélését kérheti. Ebben az esetben az elnök a kérelem beadásától számított egy hónapon belül hozza meg döntését.

\section{Magyarország}

Nem vehető fel előleg a kártérítésből.

\section{A kártérítési igény érvényesítésével kapcsolatos tájékoztatás formái Ausztria}

A VOG-ról szóló információ a Szociális és Fogyasztóvédelmi Szövetségi Minisztérium (Bundesministerium für Soziales und Konsumentenschutz) honlapjáról (http://www.bmsk.gv.at) szerezhető be a Leistungen/Behinderung/Entschädigung (Szolgáltatások/Fogyatékosság/Kártérítés) linkre kattintva. A VOG alapján az állami támogatás formanyomtatvány nélkül igényelhető.

\section{Németország}

Elvileg a kérelem előterjesztése formanyomtatvány nélkül is lehetséges. A kérelemhez ürlapok az illetékes tartományi nyugdíjhatóságoknál szerezhetők be, amelyek tanácsokkal is ellátják a büncselekmények áldozatait. További információk kaphatók a témáról például a szociális hatóságoknál, a társadalombiztosítási szerveknél, betegbiztosítóknál, biztosítóknál és a rendőrségen. A Szövetségi Egészségügyi Minisztérium (Bundesministerium für Gesundheit) ki fog adni egy tájékoztatót az áldozatok németországi kártalanításáról, amelyet a polgárok és a hatóságok is ingyenesen igényelhetnek. Ezen felül a minisztérium internetes oldaláról (http://www.bmg.bund.de) letölthetök a törvényszövegek és az áldozatok kártalanításával kapcsolatos további információk. A törvények végrehajtásáért felelős tartományok is adnak ki megfelelő tájékoztató anyagokat, és mindenkori internetes oldalukon további információk állnak rendelkezésre. Nincs külön hivatalos telefonszám a büncselekmények áldozatai számára, azonban a rendőrség általános vészhívószámán ők is bármikor segítséget kaphatnak.

\section{Egyesült Királyság}

- Anglia és Wales

A szükséges formanyomtatványok és az igénylés módjáról további felvilágosítás az Egyesült Királyság területéről telefonálók számára a 0800358 3601, a külföldröl telefonálók számára pedig a 00441413312726 számon kaphatók. Ugyanez a tájékoztatás található a CICA honlapján (https://www.cica.gov.uk). E-mailben az alábbi címen lehet tudakozódni: enquiries.cica@gtnet.gov.uk.

- Skócia

Ugyanaz a szabály érvényesül, mint Angliában és Walesben. 
- Észak-Írország

A szükséges formanyomtatványok és az igénylés módjáról felvilágosítás kapható a belfasti The Compensation Agency (Kárenyhítési Hivatal) nevü szervezetnél (e-mail: compagency@nics.gov.uk), valamint a szintén belfasti Victim Support for Northern Irelandnél (Észak-Írországi Áldozatsegítő Szervezetnél, e-mail info@ victimsupportni.org.uk). Az igénylőlapokat is tartalmazó információs csomagok az észak-írországi rendőrségtől is beszerezhetök.

\section{Franciaország}

A témával kapcsolatban felvilágosítással szolgálhatnak az Igazságügyi Minisztérium által elismert áldozatsegítő szervezetek - amelyek felsorolása az Igazságügyi Minisztérium honlapján (http://www.justice.gouv.fr) tekinthető meg -, az áldozatok segítésére szakosodott ügyvédi irodák, illetve az Elsőfokú Bíróságok mellett felállított Büncselekmények Áldozatainak Kárenyhítési Bizottságai.

Az áldozatok hívhatják továbbá az INAVEM (több áldozatsegítő szervezetet tömörítő hálózat) országos áldozatsegítő hívószámát: 0810098609.

\section{Magyarország}

A szükséges nyomtatvány letölthető a világhálóról: http://www.im.hu/aldozatsegites.

A szükséges nyomtatvány az Igazságügyi Hivatal területi szerveitől is kérhető. A területi szervek elérhetőségét az alábbi ingyenesen hívható telefonszámról is meg lehet szerezni: 0680-244-444.

\section{A kártérítési igény benyújtásához kapcsolódó jogsegély Ausztria}

A VOG rendelkezéseinek végrehajtásáért felelős hatóság természetesen készséggel nyújt tanácsot az állami támogatási lehetőségekről, és segít a kérelem elkészítésében is.

A VOG keretében azonban ügyvédi szolgáltatások igénybevétele nem lehetséges.

\section{Németország}

A kártérítési kérelem elbírálására szolgáló közigazgatási eljárás költségmentes. Ugyancsak költségmentes egy esetlegesen ezt követő eljárás az illetékes szociális bíróság előtt.

\section{Egyesült Királyság}

- Anglia és Wales

Amennyiben a sértett szükségesnek tartja, ügyvédhez vagy jogi tanácsadó szolgálathoz fordulhat jogi segítségért a kérelem elkészítésekor. A Sértettsegítő Rendszerek nem nyújthatnak jogi tanácsadást. Amennyiben a sértett úgy dönt, hogy jogi vagy egyéb térítésköteles tanácsadást kér az igénylölap kitöltéséhez, a CICA nem térítheti meg a költségeket.

- Skócia

Ugyanaz a szabály érvényesül, mint Angliában és Walesben.

- Észak-Írország

A kártérítés igényléséhez nincs szükség sem jogi tanácsadásra, sem ügyvédi képviseletre. Amennyiben a sértett mégis úgy érzi, segítségre van szüksége a kérelemmel kapcsolatban, felveheti a kapcsolatot az Észak-Írországi Sértettsegítő Szervezettel. A Sértettsegítő Szervezet azonban nem nyújthat jogi tanácsadást. Szakszervezeti tagok a szakszervezethez is fordulhatnak segítségért. 


\section{Franciaország}

A jogsegély biztosításáról a 2002. szeptember 9-i törvény rendelkezik, amit a legsúlyosabb büncselekmények sértettjei anyagi megkötés nélkül igénybe vehetnek. Más esetekben a jogsegély biztosítása két feltételhez kötött: anyagi feltétel és a kereset elfogadhatósága.

\section{Magyarország}

A kérelem kitöltéséhez az Igazságügyi Hivatal területi áldozatsegítő szolgálatai törvényi kötelezettség alapján adnak segítséget.

\section{A kártérítési kérelem benyújtásának helye}

\section{Ausztria}

A kérelmeket a Bundessozialamthoz (a Szövetségi Szociális Hivatala) kell címezni, amelynek minden tartományban van kirendeltsége. A külföldön lakó kérelmezőknek a bécsi kirendeltséghez kell kérelmüket küldeniük, a Babenbergerstraße 5, 1010 Wien címre.

\section{Németország}

A kártérítési kérelem tárgyában a határozatot a tartományok helyben illetékes nyugellátási hivatalai hozzák meg. A kérelmet azonban bármelyik más szociális hatóságnál is be lehet nyújtani.

\section{Egyesült Királyság}

- Anglia és Wales

A kitöltött kérelmet az alábbi címre kell beküldeni:

The Criminal Injuries Compensation Authority (Bünügyi Kárenyhítési Igazgatóság); Tay House 300 Bath Street, Glasgow, G2 4LN

- Skócia

- Észak-Írország

A Kárenyhítési Hivatalhoz: The Compensation Agency; Royston House 34 Upper Queen Street, Belfast, BT1 1FD

\section{Franciaország}

A kárenyhítés iránti kérelmet ahhoz az Elsőfokú Bíróság mellett felállított Büncselekmények Áldozatainak Kárenyhítési Bizottságához kell benyújtani, amely a kérelmező lakóhelyéhez vagy a büncselekmény helyéhez legközelebb található.

\section{Magyarország}

A kérelmet be lehet nyújtani az Igazságügyi Hivatal területi áldozatsegítő szolgálatainál.

\section{A sértettsegítő szervezetek Ausztria}

Jelenleg a büncselekmények áldozatainak megsegítésével foglalkozó legfőbb szervezetet, a Weißer Ringet (Fehér Gyürü) érdemes megemlíteni.

\section{Németország}

Egész sor olyan magánszervezet létezik, amelyek feladatul tüzték ki a büncselekmények áldozatainak megsegítését. Lentebb megtalálhatók a helyi szerveződésű, valamint a szövetségi köztársaság egészében megszervezett csoportok is. Ezeket az Arbeitskreis der Opferhilfen in 
der Bundesrepublik Deutschland e. V., rövidítve ADO nevü szervezet fogja össze (http://www.opferhilfen.de).

Egyesült Királyság

- Anglia és Wales

A „Victim Support” (Áldozatsegítő) nevü független jótékonysági szervezet nyújt ingyenes és bizalmas erkölcsi és gyakorlati támogatást a sértettek számára. A szervezet segítséget nyújt az igénylölap

kitöltéséhez, és tájékoztatást ad a rendszerről (http://www.victimsupport.org). Felvilágosítást nyújthat még bármelyik Állampolgári Tájékoztató Hivatal (Citizens' Advice Bureau, http://www.citizensadvice.org.uk) és a szociális jogi szervezetek is.

- Skócia

Ugyanaz a szabályozás érvényesül, mint Angliában és Walesben.

- Észak-Írország

Ugyanaz a szabályozás érvényesül, mint Angliában és Walesben.

\section{Franciaország}

$\mathrm{Az}$ áldozatsegítő szervezetek közül néhány az INAVEM (Institut National d'Aide aux Victimes et de Médiation) -hálózat tagja (országos áldozatsegítő hívószám: 08100986 09). Az Igazságügyi Minisztérium honlapján (http://www.justice.gouv.fr) elhelyezett térkép segítségével a kérelmező megkeresheti a lakóhelyéhez legközelebb található szervezeteket.

Létezik például a büncselekmények áldozatainak állam általi kárenyhítésére létrehozott bizottság, a Comités d'Imdemnisation des Victimes d'Infraction (CIVI), a Terrorcselekmények és más Büncselekmények Áldozatainak Garanciaalapja (FGTI), valamint az Igazság és Jog Háza (Maison de Justice), amelyet a kilencvenes évek elején hoztak létre azzal a céllal, hogy minél közelebb kerüljön az állampolgárokhoz az igazságszolgáltatás.

\section{Magyarország}

A Magyar Köztársaság területén több olyan civil szervezet is müködik, amelyek a büncselekmények áldozatainak segítésével foglalkoznak. Ezek egy része meghatározott áldozati kört (pl.: nőket), míg mások meghatározott büncselekmények (pl.: lakásokat érintő büncselekmények) következtében áldozattá vált személyeket segítenek. Ilyenek például a Sors-Társak Egyesület (lakásmaffia áldozatai), valamint a NANE (Nők a Nőkért Együtt az Erőszak Ellen) Egyesület (családon belüli erőszak esetén).

Emellett müködik az országban 68 áldozatvédelmi iroda, amelyeket a rendőrség, az önkormányzatok és civil szervezetek, így különösen a Fehér Gyürü Közhasznú Egyesület tartanak fenn.

Legjelentősebbnek mondható az 1989-ben, német mintára alakult Fehér Gyürü Közhasznú Egyesület.

\section{Diszkusszió és konklúzió}

A fentiek ízelítőt adnak az Európai Unió néhány tagállamának áldozatsegítési módozatairól. Jól látható, hogy az egyes tagállamokban választott megoldások a nemzetközi dokumentumokban rögzített elvárásokhoz igazodva közelednek egymáshoz. Az áldozatok jogérvényesítési lehetőségeinek akciórádiusza ennek ellenére bizonyos országokban a többihez képest jelentősen eltérés. A különböző országok és ország-csoportok gyakorlatában tapasztalható különbségek ellenére az áldozatok számára a lehető legszélesebb körben kell 
lehetővé tenni a jogi szolgáltatások igénybevételének lehetőségét, és a szolgáltatásokat az áldozatok számára minél könnyebben elérhetővé kell tenni.

Az Európai Unió vizsgált tagállamainak áldozatsegítő gyakorlatát elemezve az áldozatsegítés optimális módozata, ideáltípusa a következőképp rajzolódik ki:

\section{A bünelkövető általi jóvátétel}

- A kártérítési igény érvényesítésének feltételei

A bűnelkövetővel szemben a büntetőeljárás során büncselekmény sértettje vagy örököse, illetve mindazok, akik a büncselekmény által közvetlenül okozott kárt személyesen elszenvedték, kártérítést kérhetnek mind a büncselekmény eredményeként elszenvedett anyagi veszteségek vonatkozásában, mind a lelki sérelem tekintetében, és az összeg elvileg korlátlan.

- A kártérítési igény érvényesítésének lehetőségei az eljárás egyes szakaszaiban

A kérelem már a nyomozati eljárásban előterjeszthető, még a büntetőeljárás bírósági szakba jutása előtt, illetve még az ítélethirdető tárgyaláson is bejelenthető.

- Hogyan és kinek jelenthető be a kártérítési igény?

Elegendő - egy alakiságokhoz nem kötött - nyilatkozat benyújtása az elszenvedett károsodásért történő kártérítés igényléséről akár a nyomozati szakban a rendőrség vagy az ügyészség, akár a vádemelést követően a bíróság előtt. Az ügy bejelentésekor az áldozat szóban is jegyzökönyvbe mondhatja az igényét.

- Milyen formában kell előterjeszteni a kártérítési igényt?

A követelés bejelentési formájára és összegszerüségére nincs törvényi elöírás. Az eljárásban magánfélként történő részvételre vonatkozó nyilatkozatban nem kell megadni a kért kártérítés tényleges összegét, azonban legkésőbb a bírósági eljárásban meg kell határozni a kért összeget.

- Az eljárás előtt és/vagy folyamán részesülhet-e a sértett jogsegélyben?

Függetlenül attól, hogy a büntetőeljárás megindult-e, a büntetőeljárás elött áldozatsegítő szolgáltatásként a sértetteknek kérelmükre illeték- és díjmentesen jogi felvilágosítást és tanácsadást adnak (szakjogászi segítségnyújtás, ingyenes jogi tanácsadás).

Valamennyi hatóságnak folyamatosan tájékoztatniuk kell a sértetteket a folyó büntetőeljárásról. Már a nyomozási szakasz elején kötelesek tájékoztatni őket arról, hogy jogukban áll ügyvédi segítségét kérni.

Az igényt érvényesítő a vádemelést követően költségmentességet kérhet, valamint pártfogó ügyvédet vehet igénybe, ha személyi és vagyoni körülményei ezt indokolttá teszik. A legsúlyosabb büncselekmények sértettjei anyagi megkötés nélkül igénybe vehetnek jogsegélyt.

- Milyen bizonyítékokat kell előterjeszteni a kártérítési igény alátámasztásához?

A bíróságra hárul a kártérítés kérdésében való döntéshozatalhoz szükséges bizonyítás lefolytatása. Amennyiben a kérelmezett összeg mértékét nem támasztja alá a dokumentált bizonyíték, a bírónak azt a jogszabályoknak megfelelően kell megbecsülnie. Sérülés esetén a bíróság szakértői vizsgálatot rendelhet el, hogy a sérülés nagyságát hivatalból vagy a sértett kérelmére megállapítsák. A szakértői vizsgálat eredményének megszületéséig a sértett előleg folyósítását kérheti (kártérítési elöleg). 
- Biztosítanak-e a büncselekmény sértettjei számára különleges segítséget az elkövető terhére hozott ítélet végrehajtásához, amennyiben a bíróság javukra kártérítést ítél meg?

Az erre a célra rendszeresített szolgálat felveszi a kapcsolatot az elkövetővel, és segít a sértettnek az adósság behajtásában. Következésképpen a sértettnek nem kell kapcsolatba lépnie az elkövetővel. A bíróság is számos intézkedést hozhat, ha az elkövető nem teljesíti fizetési kötelezettségét: elrendelheti, hogy az elkövető béréből vagy szociális biztonsági ellátásaiból vonják le a büntetés összegét. Végső esetben a bíróság börtönbüntetésre is ítélheti a fizetést elmulasztó elkövetőt.

\section{Az állam általi kárenyhítés}

- Van-e lehetőség arra, hogy a sértett az államtól vagy valamely állami szervtől kapjon kárenyhítést?

Igen, az állam létrehozott egy olyan rendszert, amely lehetővé teszi kártérítés fizetését a büncselekmény következtében testi és/vagy lelki sérelmet szenvedett személyek számára a törvényben szabályozott feltételek fennállása esetén.

- Ez a lehetőség csak meghatározott típusú büncselekmények sértettjeire korlátozódik?

Jellemzően az erőszakos jogellenes támadások elszenvedése esetében lehetőség van arra, hogy a sértett az államtól vagy valamely állami szervtől kapjon kárenyhítést.

- Ez a lehetőség csak meghatározott típusú sérelmeket elszenvedett sértettekre korlátozódik?

Jellemzően a komoly következményekkel járó sérelemért igényelhető kárenyhítés.

- A büncselekmények következtében elhalálozott sértettek rokonai vagy eltartott hozzátartozói jogosultak-e kártérítésre?

Kárenyhítésre jogosult a sértetten kívül az a természetes személy is, aki a szándékos, személy elleni erőszakos büncselekmény következtében testi épségében, egészségében súlyosan károsodott sértettnek vagy meghalt személynek az elkövetés időpontjában egy háztartásban élő egyenes ági rokona, örökbefogadója vagy nevelöszülője, örökbe fogadott vagy nevelt gyermeke, házastársa, élettársa, továbbá akinek eltartására a sértett jogszabály, végrehajtható bírósági, illetőleg hatósági határozat vagy érvényes szerződés alapján köteles volt.

- A kárenyhítési lehetőség meghatározott állampolgárságú, illetve meghatározott országban lakóhellyel rendelkező személyekre korlátozódik?

Nem, a lehetőség sem állampolgárság, sem állandó lakóhely szerint nincs korlátozva.

- Folyamodhat-e a sértett kártérítésért a szokásos tartózkodási helyéül szolgáló tagállamban, ha a büncselekményt másik országban követték el? Amennyiben igen, milyen feltételek mellett?

A sértettek akkor is folyamodhatnak kárenyhítésért, ha a cselekményt külföldön követték el, és ezt ugyanolyan feltételek mellett tehetik meg, mintha a cselekményt a szokásos tartózkodási helyük szerinti tagállamban követték volna el.

- A fentiekhez kötelező-e bejelenteni a büncselekményt a rendőrségen?

Az áldozatnak jellemzően minden tőle telhetőt meg kell tennie az ügy felderítése érdekében, így jellemzően megkívánják azt is, hogy jelentbe be a büncselekményt. A rendőrségi feljelentés megkívánását jellemzően az a szempont indokolja, hogy ez segít annak bizonyításában, hogy erőszakos büncselekmény történt. 
- A kérelem benyújtásához meg kell-e várni a rendőrségi nyomozás vagy a büntetőeljárás végkimenetelét?

Nem szükséges kivárni a rendőrségi nyomozás vagy a büntetőeljárás befejezését.

- Amennyiben az elkövető személyazonossága ismert, először vele szemben kell megkísérelni a kártérítési igény érvényesítését?

Nem, az eljárások egymástól függetlenek.

- Amennyiben az elkövető személyazonossága nem ismert, illetve nem ítélték el, fennmarad-e a kártérítési jogosultság? Amennyiben igen, milyen bizonyítékokat kell előterjeszteni a kérelem alátámasztásához?

A kártérítés megítélése teljesen független a tettes büntetőjogi felelősségre vonásától. A kérelmezőnek bizonyítania kell a kérelmet megalapozó tényeket, különösen az erőszakos büncselekménynek a sérelmére történt elkövetését és az azzal okozott károsodást.

- Elévül-e a kártérítési igény benyújtásának lehetősége?

Jellemzően az erőszakos büncselekmény elkövetésének időpontjától számított három éven belül kell benyújtani a kifizetésre vonatkozó kérelmet.

- Milyen károk esetén kérhető kárenyhítés?

Bármilyen kárért kérhető kártérítés, még az elszenvedett erkölcsi kárért is.

- Hogyan történik a kártérítési összeg kiszámítása?

Sérülés esetén a sértett az alábbiak után juthat az áldozat kártérítéshez: (1) gyógykezelés költségei és (2) egyéb személyes kiadások, (3) keresetkiesés, (4) testi vagy (5) lelki szenvedés és (6) különös hátrányok. A kárenyhítést egy összegben vagy havi járadékként kell fizetni.

- Meg van-e szabva a kártérítésre megítélhető összeg alsó és/vagy felső határa?

Alapjában az állami támogatás vonatkozásában nincsen felső vagy alsó határ.

Az elv a teljes körü kárenyhítés.

- Az állam által nyújtott kárenyhítés összegéből levonják-e az azonos kárért más forrásból (például biztosítás) már megkapott vagy járó kártérítés összegét?

Csak azon szolgáltatásokat veszik számításba, amit az áldozat ugyanazon károsodásra tekintettel ténylegesen megkap, és amelyeknek így ugyanazon célt kell betölteniük.

A támogatás kiszámításakor figyelembe veszik az elkövető által fizetett kártérítést, az állami járadékokat és a kötelező társadalombiztosítás alapján járó kártérítési kifizetéseket.

Figyelmen kívül hagyják azonban a magán balesetbiztosításból származó kifizetéseket.

- Van-e bármely más feltétel, amelynek teljesítése révén megnövelhető a kártérítéshez jutás esélye, illetve amely befolyásolhatja a kártérítés mértékének kiszámítását, például magának a sértettnek a sérelmet okozó eseménnyel kapcsolatos magatartása?

Amennyiben a sértett magatartása hozzájárult a kár bekövetkeztéhez vagy mértékéhez, a megítélt kártérítés ennek megfelelöen csökkenthető.

- Felvehető-e előleg a kártérítésből? Amennyiben igen, milyen feltételek mellett?

Pénzügyi szükséghelyzetben a kártérítés megelőlegezhető. 
A betegápolási szolgáltatások azonnal nyújthatók, illetve azok költségei átvállalhatók.

- Hol szerezhetők be a szükséges formanyomtatványok és a kérelem benyújtásának módjára vonatkozó további információk? Van-e külön az erre a célra igénybe vehető segélyvonal vagy honlap?

Elvileg a kérelem előterjesztése formanyomtatvány nélkül is lehetséges.

A témával kapcsolatban felvilágosítással szolgálhatnak az igazságügyi minisztérium által elismert áldozatsegítő szervezetek, amelyek felsorolása és elérhetősége az igazságügyi minisztérium honlapján tekinthető meg.

- A kérelem elkészítéséhez részesülhet-e a sértett jogsegélyben?

Jogsegélyt a sértettek anyagi megkötés nélkül igénybe vehetnek a kérelem elkészítéséhez is.

- Hova kell beküldeni a kérelmet?

A kérelmet bármelyik szociális hatóságnál be lehet nyújtani.

- Létezik-e olyan sértetteket segítő szervezet, amelyhez a sértett további segítségért folyamodhat?

Egész sor olyan civil szervezet, egyesület és alapítvány létezik, amelyek feladatul tüzték ki a büncselekmények áldozatainak megsegítését.

Az áldozatok tájékoztatást kaphatnak az áldozatok információs pontjától is, valamint az áldozatvédelmi irodáktól, amelyek az áldozatok lakóhelyéhez közel, a kisebb közigazgatási egységekben találhatók.

A fentiek igazolják, hogy az EU tagállamokban az igazságszolgáltatás nem hagyja magára a bajba került áldozatot. A különböző jogrendszerek sokféle lehetőséget kínálnak az áldozatok számára. Lényeges azonban, hogy ezekről a szükséghelyzetben lévők kellő időben korrekt tájékoztatást kapjanak. Ennek érdekében a társadalom széles rétegeit elérő kommunikációs csatornák nyújtotta lehetőséget minél szélesebb körben kell igénybe venni. A lehetőségek tehát adottak, csak tudnunk kell élni velük.

Mivel mindannyian válhatunk áldozattá, megszívlelendő az alábbi horatiusi megállapítás: „Célom: a dolgokon én legyek úr, s ne rajtam a dolgok”.

\section{Források:}

1. Dr. Kiss Anna: Gondolatok Barabás A. Tünde: Börtön helyett egyezség? című könyvéröl, Magyar Jog, 2005/4. 243-247. p.

2. http://ec.europa.eu/civiljustice/comp_crime_victim/comp_crime_victim_gen_hu.htm

3. http://www.bmj.bund.defiles-3310pferfibel.pdf

4. http://www.anwaelte-spadenteich.de/Laesst_die_Justiz_die_Opfer_allein.pdf -

5. http://www.juris.de

6. http://www.opferhilfen.de

7. http://www.citizensadvice.org.uk

8. htpp://www.victimsupport.org

9. htpp://www.justice.gouv.fr

10. http://www.kih.gov.hu/alaptev/partfogo/mediacio/mediacio.html?pagenum=3

11. http://www.bmsk.gv.at/cms/basb/detail.html?channel=CH0457\&doc=CMS109221873374 9

[1] PhD-hallgató, ELTE-ÁJK Kriminológiai Tanszék 
